\title{
ANALISIS PENERAPAN KONSEP GLAM (GALLERY, LIBRARY, ARCHIVES, MUSEUM) DI PERPUSTAKAAN BUNG KARNO BLITAR
}

\author{
Kurniasih Yuni Pratiwi, Suprihatin, Bambang Setiawan \\ Perpustakaan Universitas Brawijaya, Malang \\ e-mail: pratiwikurnia399@gmail.com,pri.suprihatin@gmail.com, bambangseptiawan20@gmail.com
}

\begin{abstract}
ABSTRAK
GLAM (Gallery, Library, Archive, and Museum) merupakan konsep yang saling berkesinambungan dan memiliki kesempatan untuk bekerjasama menciptakan Four Cultural Heritage Domains. Di Indonesia konsep GLAM sudah ada, akan tetapi belum ada yang menerapkannya, Perpustakaan Proklamator Bung Karno diharapkan dapat mengakomodir dan menjadi acuan terciptanya konsep GLAM karena hal ini sangat penting dilakukan sebagai tantangan kepustakawanan di era disruptif dan juga untuk meningkatkan kompetensi pustakawan (berbasis SKKNI) dalam ekosistem digital. Konsep GLAM atau dikenal dengan Four Cultural Heritage Domains sangat bagus dikembangkan dan diterapkan di Indonesia agar kegiatan dan pelayanan kepada masyarakat lebih bagus lagi. Penelitian ini merupakan study literatur di Perpustakaan Bung Karno Blitar karena Perpustakaan Proklamator Bung Karno sudah memenuhi kriteria Four Cultural Heritage Domains dan sudah memenuhi konsep GLAM sehingga harusnya tidak hanya perpustakaannya saja yang diunggulkan tetapi juga gallery, archive dan museum juga harus dimaksimalkan keberadaannya. Dengan adanya penerapan konsep GLAM di Perpustakaan Bung Karno diharapkan dapat menjadi pelopor munculnya konsep GLAM oleh perpustakaan lain di Indonesia. Konsep GLAM diharapkan dapat menarik minat kunjungan masyarakat ke kota Blitar tidak hanya dari dalam kota maupun luar kota, tetapi diharapkan dari mancanegara juga berkunjung ke Perpustakaan Bung Karno karena di sana banyak sekali menyimpan fakta sejarah dan perjuangan bangsa Indonesia. Keberadaan sosok seorang Soekarno sebagai Presiden Pertama di Indonesia akan menjadi daya tarikyang luar biasa apabila dijadikan konsep yang menarik untuk mengemas informasi yang ada di Perpustakaan Proklamator Bung Karno.
\end{abstract}

Kata Kunci: Galeri, Perpustakaan, Arsip, Museum, GLAM, Perpustakaan Proklamator Bung Karno

\section{PENDAHULUAN}

Perkembangan ilmu pengetahuan dan teknologi yang sangat pesat membawa dunia memasuki gelombang peradaban baru yang disebut sebagai era informasi. Era baru ini ditandai dengan ledakan informasi (information explosion) serta mendorong lahir dan berkembangnya teknologi informasi (information technology). Informasi baru muncul dalam hitungan tiap detik, mampu menembus batas-batas geografis dengan kecepatan yang luar biasa karena dikemas dan dikelola sedemikian canggihnya. Akibatnya, manusia tidak lagi memiliki kesulitan untuk mengakses bermacam-macam informasi baru. Perubahan era ini memberikan dampak yang sangat signifikan terhadap beberapa institusi misalnya perpustakaan dan kearsipan. Tingginya kebutuhan masyarakat akan informasi, ketersediaan informasi yang sangat beraneka ragam, gelombang informasi baru yang sangat cepat, serta teknologi informasi yang semakin canggih, mendorong perpustakaan untuk mampu menerapkan teknologi dan manajemen informasi yang handal.

Kemajuan teknologi informasi dan telekomunikasi begitu pesat, sehingga memungkinkan diterapkannya cara-cara baru yang lebih efisien untuk produksi, distribusi dan konsumsi barang dan jasa. Informasi harus dikemas sedemikian rupa agar pengguna dapat memanfaatkan fasilitas yang ada dengan semaksimal mungkin. Menyikapi kondisi seperti itu, perpustakaan harus dapat mengikuti tuntutan zaman, yaitu dengan pengelolaan, pola layanan, perawatan dan pelestarian serta sistem penyebaran informasi yang tepat guna. Maka keberadaan pustakawan sangat dibutuhkan sebagai mediator dan fasilitator informasi untuk menyikapi semakin tingginya tuntutan pemustaka agar perpustakaan dapat meningkatkan mutu layanannya. Dengan demikian, perpustakaan harus didukung oleh sumber daya manusia perpustakaan yang profesional, yaitu pustakawan yang memiliki kompetensi bidang perpustakaan dengan 
berpedoman pada Standar Kompetensi Kerja Nasional Indonesia - Perpustakaan (SKKNI - PRP).

Konsep kolaborasi antara Gallery, Library, Archive and Museum atau yang dikenal dengan GLAM belum marak di Indonesia karena masing-masing instansi masih belum menjadi satu dan di bawah naungan badan atau kementerian sendiri-sendiri. Padahal konsep GLAM ini apabila dapat dipersatukan akan menjadi sebuah kolaborasi yang sangat menarik karena masing-masing memiliki nilai budaya maupun memiliki keunikan yang beragam dan kemudahan informasi yang didapat pengguna akan lebih mudah dan cepat.

Hubungan antara Gallery, Library, Archive dan Museum sesungguhnya tidak dapat dipisahkan dan setiap instansinya memungkinkan untuk bekerjasama dan berkolaborasi, karena apabila ditinjau dari ilmu dokumentasi hubungan diantara setiap instansi sangat erat kaitannya dengan dokumentasi dalam arti luas, yakni mengumpulkan, mengadakan, mencatat, menyimpan, merawat, mengolah koleksi dan menyajikan atau mengomunikasikannya untuk publik. Perpustakaan Proklamator Bung Karno sebenarnya memiliki potensi sebagai konsep GLAM namun saat ini yang diutamakan hanya konsep perpustakaannya saja karena masih ada dalam naungan atau di bawah Perpustakaan Nasional RI, sehingga keberadaannya kurang dikenal oleh masyarakat Indonesia padahal di lingkungan perpustakaan Proklamator Bung Karno terdapat juga barang-barang bersejarah yang memiliki nilai budaya yang tinggi karena semua peninggalan Bung Karno ada di sana bahkan makan Bung Karno juga berada di komplek perpustakaan.

\section{TINJAUAN LITERATUR}

\section{Pengertian SKKNI - PRP}

Standar Kompetensi Kerja Nasional Indonesia - Perpustakaan (SKKNI - PRP) adalah rumusan kemampuan kerja yang mencakup aspek pengetahuan, keterampilan dan/atau keahlian serta sikap kerja yang relevan dengan pelaksanaan tugas dan syarat jabatan yang ditetapkan sesuai dengan ketentuan peraturan perundangundangan yang berlaku.

Dengan dikuasainya standar kompetensi tersebut oleh seseorang, maka yang bersangkutan akan mengetahui dan memiliki kemampuan tentang:

- Bagaimana mengerjakan suatu tugas atau pekerjaan.

- Bagaimana mengorganisasikannya agar pekerjaan tersebut dapat dilaksanakan.

- Apa yang harus dilakukan bilamana terjadi sesuatu yang berbeda dengan rencana semula.
- Bagaimana menggunakan kemampuan yang dimilikinya untuk memecahkan masalah atau melaksanakan tugas dengan kondisi yang berbeda.

- Bagaimana menyesuaikan kemampuan yang dimiliki bila bekerja pada kondisi dan lingkungan yang berbeda.

Model Standar Kompetensi SKKNI Bidang Perpustakaan dikembangkan dengan mengacu pada Permenakertrans No. 21/MEN/2007 tentang Tata Cara Penetapan SKKNI dan atas dasar penetapan tersebut maka standar kompetensi kerja bidang perpustakaan yang dikembangkan harus mengacu kepada Regional Model of Competency Standard (RMCS).

Prinsip yang Harus Dipenuhi dalam Penyusunan Standar dengan Model Standar Kompetensi Regional (RMCS). Penyusunan dan perumusan SKKNI yang merefleksikan kompetensi tenaga kerja yang dibutuhkan oleh dunia usaha dan industri harus memenuhi beberapa hal sebagai berikut:

1. Fokus pada kebutuhan sektor jasa difokuskan pada kompetensi kerja yang berlaku dan dibutuhkan oleh sektor jasa, dalam upaya melaksanakan proses bisnis sesuai dengan tuntutan operasional perusahaan yang dipengaruhi oleh dampak era globalisasi.

2. Kompatibilitas memiliki kompatibilitas dengan standar-standar yang berlaku di sektor bidang pekerjaan yang sejenis dan kompatibel dengan standar sejenis yang berlaku di negara lain atau internasional.

3. Fleksibilitas memiliki sifat umum yang mampu mengakomodasi perubahan dan penerapan kemajuan ilmu pengetahuan dan teknologi yang diaplikasikan dalam bidang pekerjaan yang terkait.

4. Ketelusuran Standar harus memiliki sifat ketelusuran yang tinggi sehingga dapat menjamin:

5. Transferlibilitas

- Terfokus pada keterampilan dan pengetahuan yang dapat dialihkan ke dalam situasi maupun di tempat kerja yang baru.

- Aspek pengetahuan, keterampilan dan sikap kerja terumuskan secara holistik (menyeluruh).

\section{Definisi GLAM}

\section{Gallery (Galeri)}

a. Definisi Galeri

Menurut arti bahasanya, pengertian galeri merupakan selasar atau tempat; dapat pula diartikan sebagai tempat yang memamerkan karya seni tiga dimensional karya seorang atau kelompok seniman 
atau bisa juga didefinisikan sebagai ruangan atau gedung tempat untuk memamerkan benda atau karya seni. Menurut Pusat Bahasa Departemen Pendidikan, (2003). Sedangkan menurut Oxford advanced learner's dictionary, A.S Hornby, edisi kelima menyatakan bahwa Gallery: a room or building ofr showing works of art".

Dalam kamus Inggris - Indonesia, An EnglishIndonesian Dicionary,(1990): "Galeri: Serambi, balkon, balai atau gedung kesenian". Sedangkan menurut Encyclopedia of American Architecture (1975), Galeri diterjemahkan sebagai suatu wadah untuk menggelar karya seni rupa. Galeri juga dapat diartikan sebagai tempat menampung kegiatan komunikasi visual di dalam suatu ruangan antara kolektor atau seniman dengan masyarakat luas melalui kegiatan pameran. Sebuah ruang yang digunakan untuk menyajikan hasil karya seni, sebuah area memajang aktivitas publik, area publik yang kadangkala digunakan untuk keperluan khusus (Dictionary of Architecture and Construction, 2005).

Menurut Djulianto seorang arkeolog, galeri berbeda dengan museum. Galeri adalah tempat untuk menjual benda/karya seni, sedangkan museum tidak boleh melakukan transaksi karena museum hanya merupakan tempat atau wadah untuk memamerkan koleksi bendabenda yang memiliki nilai sejarah dan langka (Koran Tempo, 2013).

\section{b. Fungsi Galeri}

Galeri memiliki fungsi utama sebagai wadah/alat komunikasi antara konsumen dengan produsen. Pihak produsen yang dimaksud adalah para seniman sedangkan konsumen adalah kolektor dan masyarakat. Fungsi galeri menurut Kakanwil Perdagangan antara lain:

1. Sebagai tempat promosi barang-barang seni.

2. Sebagai tempat mengembangkan pasar bagi para seniman

3. Sebagai tempat melestarikan dan memperkenalkan karya seni dan budaya dari seluruh Indonesia.

4. Sebagai tempat pembinaan usaha dan organisasi usaha antara seniman dan pengelola.

5. Sebagai jembatan dalam rangka eksistensi pengembangan kewirausahaan.

6. Sebagai salah satu objek pengembangan pariwisata nasional.

c. Jenis-jenis Galeri

Jenis-jenis galeri dapat dibedakan sebagai berikut:

1. Galeri di dalam museum

Galeri ini merupakan galeri khusus untuk memamerkan benda-benda yang dianggap memiliki nilai sejarah ataupun kelangkaan.
2. Galeri kontemporer

Galeri yang memiliki fungsi koersal dan dimiliki oleh perorangan.

3. Vanity Gallery.

Galeri seni artistik yang dapat diubah menjadi suatu kegiatan didalamnya, seperti pendidikan dan pekerjaan.

4. Galeri arsitektur

Galeri untuk memamerkan hasil karya-karya di bidang arsitektur yang memiliki perbedaan antara 4 jenis galeri menurut karakter masing-masing

5. Galeri komersial

Galeri untuk mencari keuntungan, bisnis secara pribadi untuk menjual hasil karya. Tidak berorientasi mencari keuntungan kolektif dari pemerintah nasional atau lokal.

\section{Library (Perpustakaan)}

a. Definisi Perpustakaan

Menurut IFLA (International of Library Associationsand Institutions) Perpustakaan merupakan kumpulan bahan tercetak dan non tercetak dan atau sumber informasi dalam komputer yang tersusun secara sistematis untuk kepentingan pemakai. Sedangkan menurut Sutarno. "perpustakaan adalah suatu ruangan, bagian dari gedung/bangunan, atau gedung itu sendiri, yang berisi buku-buku koleksi, yang disusun dan diatur sedemikian rupa sehingga mudah dicari dan dipergunakan apabila sewaktu-waktu diperlukan untuk pembaca.

Sedangkan di dalam Kamus Besar Bahasa Indonesia (KBBI) Perpustakaan berasal dari kata dasar "pustaka" yang berarti pustaka atau buku. "Perpustakaan" artinya kumpulan buku (bacaan dsb), dan di dalam UU No.43 tahun 2007 tentang perpustakaan disebutkan bahwa: Perpustakaan adalah institusi pengelola koleksi karya tulis, karya cetak, dan/atau karya rekam secara profesional dengan sistem yang baku.

b. Fungsi Perpustakaan

Dalam pasal 3 UU No.43 2007 disebutkan Perpustakaan berfungsi sebagai wahana pendidikan, penelitian, pelestarian, informasi, dan rekreasi untuk meningkatkan kecerdasan dan keberdayaan bangsa. Fungsi pendidikan diwujudkan dengan perpustakaan yang mampu meningkatkan kegemaran membaca penggunanya. Fungsi penelitian diterapkan dengan menyediakan pelayanan untuk pemakai dalam memperoleh informasi sebagai bahan rujukan untuk kepentingan penelitian. Fungsi pelestarian yaitu sebagai tempat melestarikan bahan pustaka (bahan pustaka merupakan sumber ilmu 
pengetahuan, teknologi, dan budaya). Fungsi informasi diterapkan dengan menyediakan sumber-sumber pustaka yang lengkap dan bermutu. Fungsi rekreasi diterapkan dengan menyediakan buku hiburan dan tata ruang yang bersifat rekreatif. Selain fungsi-fungsi tersebut, ada pula fungsi sosial, yang diartikan sebagai wadah sosialisasi antar pengunjung dalam memperoleh informasi.

c. Jenis-jenis perpustakaan

1. Perpustakaan Nasional

Perpustakaan Nasional merupakan Lembaga Pendidikan Non Departemen (LPND) yang melaksanakan tugas pemerintah dalam bidang perpustakaan dan berkedudukan di Ibukota negara.

2. Perpustakaan Umum

Perpustakaan umum merupakan perpustakaan yang bertugas mengumpulkan, menyimpan, mengatur dan menyajikan bahan pustakanya untuk masyarakat umum. Perpustakaan umum diselenggarakan untuk memberikan pelayanan kepada masyarakat umum tanpa memandang latar belakang pendidikan, agama, adat istiadat, umur, jenis dan lain sebagainya.

3. Perpustakaan Sekolah/Madrasah

Perpustakaan yang memiliki koleksi buku teks pelajaran yang ditetapkan sebagai buku teks wajib pada satuan pendidikan yang bersangkutan dalam jumlah yang mencukupi untuk melayani semua peserta didik dan pendidik

4. Perpustakaan Perguruan Tinggi

Perpustakaan perguruan tinggi yaitu perpustakaan yang diselenggarakan untuk mengumpulkan, memelihara, menyimpan, mengatur, mengawetkan dan mendayagunakan bahan pustakanya untuk menunjang pendidikan/pengajaran, penelitian dan pengabdian masyarakat

5. Perpustakaan Khusus

Perpustakaan khusus adalah perpustakaan yang diselenggarakan oleh kantor atau instansi yang tujuannya adalah untuk menunjang kegiatan kantor atau instansi dimana perpustakaan itu berada.

\section{Archive (Arsip)}

a. Definisi Arsip

Secara etimologi, istilah arsip berasal dari bahasa Yunani yaitu "Arche" yang berarti permukaan, kemudian kata arche berkembang menjadi kata "Ta Archia" yang berarti catatan, selanjutnya kata Ta Archia berubah lagi menjadi kata "Archeion" yang berarti gedung pemerintah yang di dalamnya terdapat tempat arsip dan kemudian dalam bahasa Latinnya berbunyi "archium" dari kata inilah lahir kata arsip. Sementara itu dalam bahasa Belanda kata arsip disebut "archief" dan dalam bahasa Inggris disebut "Record" yang pada hakekatnya semua berujung pada pengertian yang sama yakni penyimpanan warkat, yang bermakna suatu bentuk pekerjaan tata usaha, yang berupa penyusunan warkat dengan tujuan agar dapat dengan mudah ditemukan kembali jika dibutuhkan. Arsip sebagai simpanan surat-surat penting, dokumen tertulis yang mempunyai nilai historis, disimpan dan dipelihara ditempat khusus untuk referensi.

b. Jenis-jenis Arsip

1. Arsip Dinamis

Sukoco (2006) mendefinisikan Arsip dinamis dengan pengertian informasi terekam, termasuk data dalam sistem komputer, yang dibuat atau diterima oleh organisasi atau perorangan dalam transaksi kegiatan atau melakukan tindakan sebagai bukti aktivitas tersebut. Kemudian Anglo-Saxon yang dikutip oleh Sustiyo-Basuki (2003) mendefinisikan arsip dinamis adalah dokumen yang masih digunakan untuk perencanaan, pengambilan keputusan, pengawasan, dan keperluan lain fungsi arsip dinamis:

a. Merupakan Memori Untuk Badan Korporasi (organisasi)

b. Pengambilan Keputusan Manajemen

c. Menunjang Litigasi

d. Mengurangi Biaya dan Volume Penggunaan Kertas

e. Efisiensi Badan Korporasi (Organisasi)

f. Ketentuan Hukum

g. Rujukan Historis

2. Arsip Statis

Arsip Statis adalah arsip yang tidak digunakan lagi bagi organisasi tetapi karena nilai informasinya cukup tinggi masih tetap disimpan dan dipelihara. Dengan kata lain karena arsip yang bersangkutan memiliki nilai berkelanjutan setelah nilai bagi manajemen selesai. Data yang terkandung di dalam arsip kegunaannya beralih kepada kegunaan yang lebih luas. Bukan lagi untuk kepentingan manajemen tetapi yang utama untuk kepentingan yang sifatnya luas, seperti untuk penelitian, dan kepentingan masyarakat lainnya.

\section{Museum}

a. Definisi Museum

Menurut Peraturan Pemerintah No. 19 Tahun 1995

Tentang Museum, museum adalah lembaga, tempat 
penyimpanan, perawatan, pengamanan, dan pemanfaatan benda-benda bukti material hasil budaya manusia serta alam dan lingkungannya guna menunjang upaya perlindungan dan pelestarian kekayaan budaya bangsa.

Menurut ICOM (International Council of Museum) yang merupakan bagian dari UNESCO yang membidangi masalah permuseuman telah merumuskan definisi bahwa museum merupakan lembaga yang bersifat tetap, tidak mencari keuntungan, melayani masyarakat, dan perkembangannya, terbuka untuk umum yang memperoleh, merawat, menghubungkan dan memamerkan, untuk tujuan-tujuan studi, pendidikan dan kesenangan, barang-barang pembuktian manusia dan lingkungannya.

\section{b. Fungsi Museum}

Berdasarkan Internasional Council of Museum (ICOM) pada tanggal 14 juni 1974 di Denmark, museum berfungsi sebagai:

1. Pembangkit rasa taqwa dan bersyukur kepada Tuhan Yang Maha Esa

2. Sebagai cermin pertumbuhan peradaban umat manusia

3. Pengenalan budaya kepada masyarakat Indonesia baik itu antar daerah maupun antarbangsa

4. Visualisasi warisan alam dan budaya

5. Penyebaran serta pemerataan ilmu untuk masyarakat umum

6. Sebagai tempat penelitian ilmiah dan dokumentasi

7. Sebagai tempat pelestarian benda bersejarah yang hampir punah

8. Pengumpulan dan pengamanan warisan alam dan budaya.

\section{Lembaga yang mengaplikasikan GLAM di Luar Negeri}

IFLA (International Federation of Library Associations and Institutions)

IFLA sebuah institusi tertinggi perpustakaan telah bergabung dengan 5 institusi internasional ICA (arsip), ICOM (museum), ICOMOS (monumen \& situs) and CCAAA (arsip audio visual) telah setuju untuk bekerja sama dalam membangun semuanya dalam satu kesatuan yang bernama LAMMS (Library, Archives, Museums, Monuments, and Sites)

Fokus utama organisasi LAMMS ini antara lain:

1. Copyright dan pengaturan legalitas

2. Political lobby

3. Preservasi dan perlindungan warisan budaya
4. Perpustakaan digital secara global

5. Pengaturan standarisasi

\section{ELAG (European Library Automation Group)}

Organisasi yang bergerak dalam bidang perpustakaan digital ini dalam sebuah konfrensi menyebutkan telah mengembangkan web-base katalog, pameran secara virtual, dan koleksi full-text di dalam satu repository yang sama. Hasil yang akan ditunjukan kepada pengguna itu sendiri merupakan laporan-laporan dari setiap instansi arsip, perpustakaan, dan museum yang organisasi singkat menjadi (ALM).

NOKS (the culture historical database of the north of justland)

NOKS merupakan sebuah proyek di Denmark yang betujuan untuk membentuk suatu institusi kerjasama yang bernama ABM (Archive, Biblioteker (library), and Museum) diharapkan dalam pembentukan ABM ini dapat membantu pengguna dalam melakukan pencarian ketiga instansi dalam satu kali pencarian.

\section{Perpustakaan Proklamator Bung Karno}

Perpustakaan Proklamator Bung Karno atau yang lebih dikenal dengan Perpustakaan Bung Karno di Kota Blitar. Gedung UPT Perpustakaan Proklamator Bung Karno terletak pada Jalan Kalasan No 1 kota Blitar, Kode Pos 66133 dan berdekatan dengan pusat pemerintahan Kota Blitar. Gedung ini diresmikan oleh Presiden Republik Indonesia Megawati Soekarnoputri yang sekaligus putri kandung Bung Karno pada tanggal 3 Juli 2004 di Kota Blitar. Gambar 1. adalah tampilan website dari perpustakaan Bung Karno, terlihat patung Bung Karno sedang duduk sambil membawa buku yang menggambarkan kegemaran beliau akan literasi.

Peresmian tersebut mengacu pada surat persetujuan Menteri Pendayagunaan Aparatur negara Nomor: B/141/M.PAN/I.2005 tentang Organisasi dan Tata Kerja Unit Pelaksana Teknis Perpustakaan Proklamator Bung Karno dan Keputusan Kepala Perpustakaan Nasional Republik Indonesia Nomor: 04 Tahun 2005 Tanggal 8 Februari 2005 "Perpustakaan Proklamator Bung Karno merupakan Unit Pelaksanaan teknis (UPT) Perpustakaan Nasional Republik Indonesia yang berkedudukan di Kota Blitar yang bertanggungjawab langsung kepada Perpustakaan Nasional Republik Indonesia dan dalam operasionalnya wajib melakukan koordinasi dengan pemerintah Kota Blitar. 
Profil Perpustakaan Proklamator Bung Karno

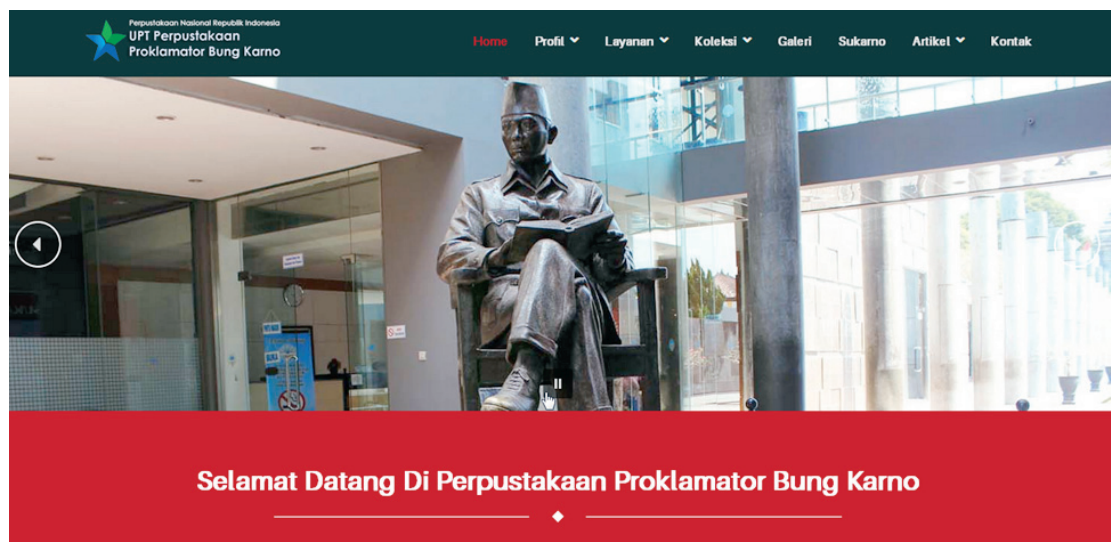

Gambar 1. Website Perpustakaan Bung Karno

Lokasi Perpustakaan Proklamator Bung Karno

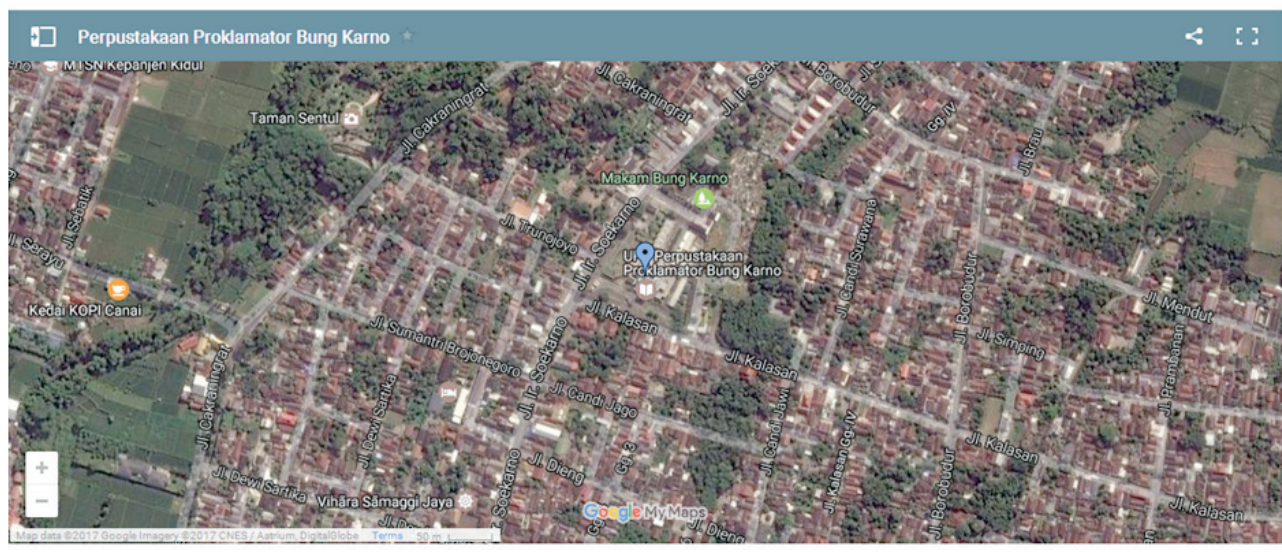

View Perpustakaan Proklamator Bung Karno in a larger map

Gambar 2. Denah lokasi Perpustakaan Bung Karno

Alamat : Perpustakaan Proklamator Bung Karno J1.Kalasan No.1 Kota Blitar Jawa Timur - Indonesia. Telepon : (0342) 815 477/Fax (0342) 815479

Email : info@perpusbungkarno.perpusnas.go.id

Jam Pelayanan: $08.00-16.00$ WIB.

\section{METODOLOGI PENELITIAN}

Kajian ini menggunakan metode penelitian deskriptif dengan pendekatan kualitatif. Menurut Sulistyo-Basuki penelitian kualitatif merupakan penelitian yang memiliki tujuan untuk memperoleh gambaran seutuhnya mengenai suatu hal yang tidak dapat diukur dengan angka (Sulistyo-Basuki, 2010). Sedangkan penelitian deskriptif menurut (Ghony, 2012) adalah penelitian yang kegiatan pengumpulan datanya dilakukan dalam bentuk kata-kata, gambar, atau apa pun selain angka, dalam penelitian ini data diambil dari video profil dan website Perpustakaan Bung Karno. Dengan menggunakan metode penelitian deskriptif kualitatif diharapkan kajian ini akan dapat memberikan gambaran mengenai bagaimana konsep GLAM dapat diterapkan di Perpustakaan Bung Karno Blitar. 


\section{PEMBAHASAN}

Gallery, library, archive, dan museum sebenarnya tidak dapat dipisahkan karena keempatnya merupakan warisan budaya yang memiliki nilai sejarah tinggi dan harus dijaga, dirawat, dipelihara dan dilestarikan keberadaannya, meskipun antara satu dengan lainnya ada keterkaitan namun dalam kenyataannya di negara kita library, archive, dan museum sangat jelas perbedaannya karena memiliki fungsi dan tugas yang berbeda-beda meskipun produk yang dihasilkan kadang memiliki kesamaan yang signifikan, di negara kita library, archive, dan museum memiliki masing-masing instansi yang menaunginya. Library di bawah naungan Perpustakaan Nasional Republik Indonesia (Perpusnas RI), archive di bawah naungan Arsip Nasional Republik Indonesia (ANRI), sedangkan museum di bawah naungan Kementerian Pariwisata (KEMENPAR) dan galeri biasanya hampir sama dengan museum karena di dalamnya memuat berbagai macam karya seni yang tak ternilai harganya.

Konsep dengan istilah GLAM sudah banyak diterapkan di luar negeri, lembaga yang mengaplikasikan
GLAM di Luar Negeri diantaranya: IFLA (International Federation of Library Associations and Institutions), ELAG (European Library Automation Group), NOKS (the culture historical database of the north of justland).

Konsep GLAM sebenarnya sangat bagus dapat diterapkan di Negara Indonesia demi peningkatan kajian-kajian tentang nasionalisme, dan memperdalam pemahaman tentang sejarah dan budaya Indonesia. Gallery, library, archive dan museum hendaknya memiliki berbagai aspek yang saling berkaitan yaitu:

1. Dinaungi dalam satu badan/kementerian saja tidak usah terpisah-pisah

2. Efisiensi anggaran dan memudahkan administrasi

3. Mendukung kajian, penelitian dan kegiatan ilmiah

4. Dapat melayani dan memenuhi kebutuhan pengguna secara maksimal

5. Kegiatan lebih terstruktur dan memudahkan masyarakat dalam memahami arti sejarah bangsa.

6. Mengenalkan produk dan koleksinya agar lebih dikenal masyarakat

\begin{tabular}{|l|}
\hline Kondisi saat ini: \\
1.Di Indonesia belum \\
dikembangkan konsep \\
GLAM \\
2.Masing-masing \\
instansi masih berdiri \\
sendiri belum menjadi \\
satu \\
3.Yang diunggulkan \\
hanya \\
perpustakaannya saja \\
4.Perpustakaan Bung \\
Karno sudah \\
memenuhi konsep \\
GLAM \\
5.Diterapkan untuk \\
memaksimalkan \\
nasionalisme dan \\
sejarah kemerdekaan \\
6.Memudahkan \\
penelitian dan study \\
tentang kebudayaan \\
dan sejarah \\
7.Menambah wawasan \\
kebangsaan \\
\hline
\end{tabular}

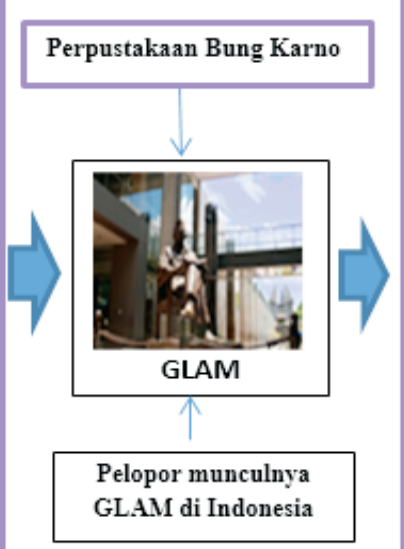

Gambar 3. Kerangka Konsep Penerapan Konsep Glam Di Indonesia, 2019
Tercapainya Konsep GLAM:

1. Galery: memiliki barangbarang bersejarah, lukisan, koper, baju Bung kamo dan foto yang dipamerkan di dalam Galery yang khsuus dan istimewa di tempat lain tidak ada.

2. Library: koleksi ada cetak maupun non cetak, beragam jenis koleksinya yang mengemban tugas meningkatkan budaya\&peradapan bangsa Indonesia.

3. Archieve: menyimpan karya Soekamo, bulkubuku yang dibaca.

Soekamo, karya orang lain tentang Soekamo dan karya para pejuang bangsa.

4. Museum: Gedung memiliki malnna filosofis terkait perjalanan hidup Bung Karno, Blitar terkenal sebagai kota proklamator dan kota peta karena berhasil melawan Jepang, letak perpustakaan menyatu degan makam bung kamo dan bangunan menyerupai dengan candi penataran.

$$
\text { . }
$$

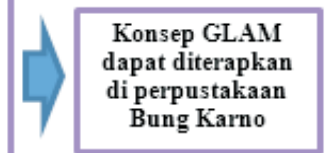

\section{.}

.

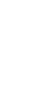

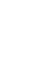

.


7. Meningkatkan kunjungan wisatawan baik dari dalam negeri maupun manca Negara

Perpustakaan bung Karno yang terletak di kota Blitar sangat menarik keberadaannya karena Kota Blitar adalah kota sejarah yang dikenal sebagai kota proklamator dan kota peta karena pada tanggal 14 Februari 1945 di bawah kepemimpinan Supriadi rakyat Indonesia berjuang merebut kemerdekaan melawan laskar Jepang. Terdapat komplek makam Bung Karno yang sangat dihargai dan menjadi kebanggaan bangsa Indonesia karena Bung karno dikenal sebagai bapak Presiden Pertama di Indonesia.

Perpustakaan Proklamator Bung Karno didirikan karena adanya keinginan yang kuat dalam mengembangkan nasionalisme Indonesia untuk menghadapi globalisme, kekaguman akan sosok Bung Karno dengan pemikiran dan cita-citanya dalam meletakkan fondasi kebangsaan Indonesia menjadi salah satu dasar dan perlunya berbagai macam aktivitas yang dipusatkan di perpustakaan Bung Karno sebagai pusat kajian dan nasionalisme di Indonesia, perpustakaan ini merupakan unit pelaksana teknis dari perpustakaan Nasional RI yang diresmikan pada tanggal 3 Juli 2004 oleh Presiden Megawati Soekarno Putri.

Penjelasan konsep GLAM di perpustakaan Proklamator Bung Karno:

\section{Gallery (Galeri)}

Memiliki barang-barang bersejarah, lukisan, koper, baju Bung Karno, foto, uang kuno, keris yang dipamerkan di dalam galeri yang khusus dan istimewa di tempat lain tidak ada, karena barang peninggalan ini memiliki nilai sejarah yang sangat tinggi sehingga koleksinya hanya dapat dilihat oleh pengguna dan tidak diperjual belikan ataupun dipindah tangan

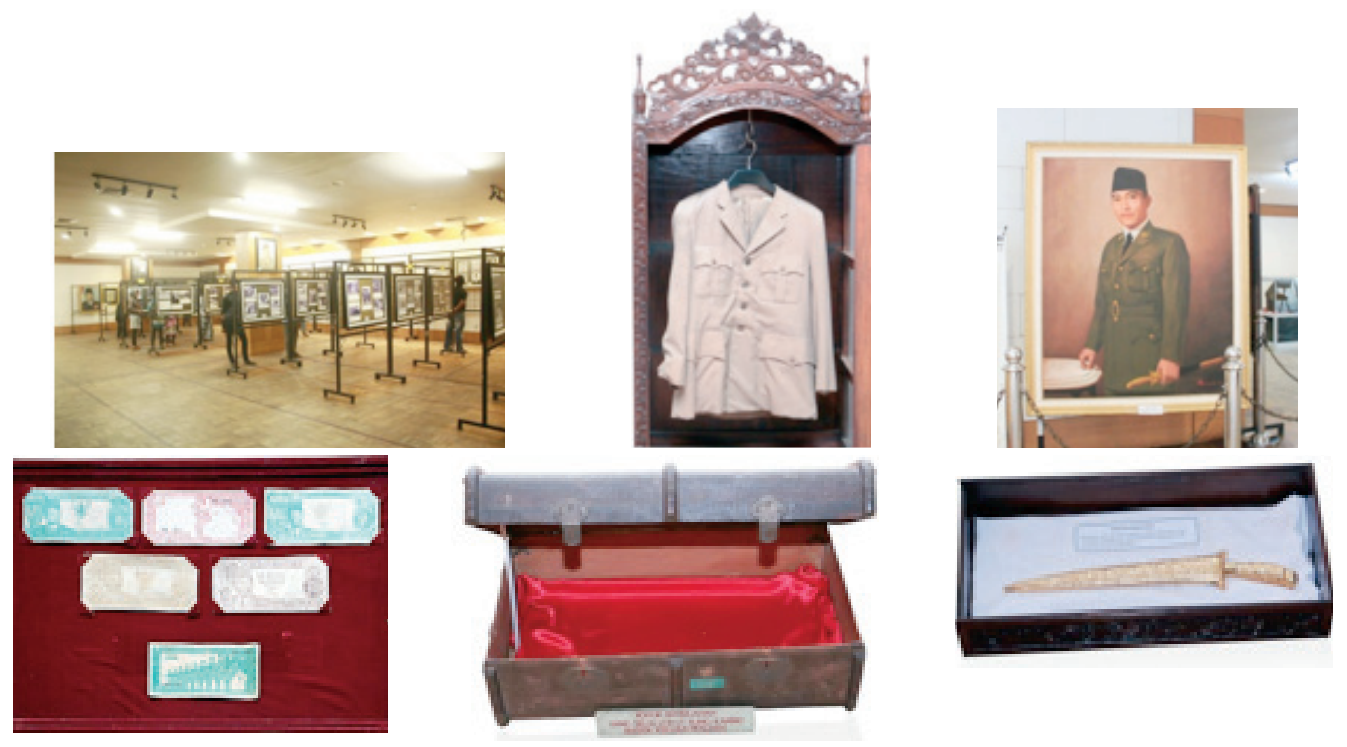

Gambar 4. Sumber: http://perpusbungkarno.perpusnas.go.id/web/index.php/galeri

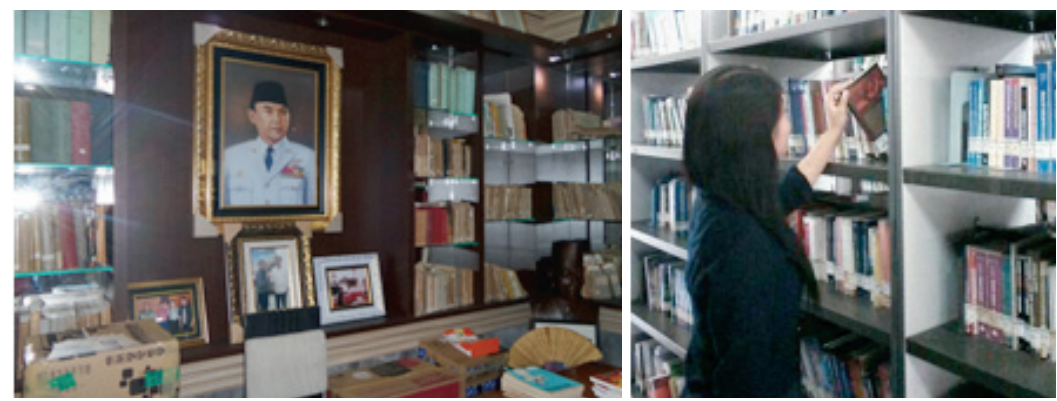

Gambar 5. Sumber: https://www.google.co.id/search?q=perpustakaan+bung+karno\&source 
kepada orang lain karena koleksi ini adalah milik negara dan menjadi kekayaan bangsa Indonesia.

2. Library (Perpustakaan)

Koleksi ada cetak maupun non cetak, beragam jenis koleksinya yang mengemban tugas meningkatkan budaya dan peradapan bangsa Indonesia berada di gambar 5 .

3. Archive (Arsip)

Menyimpan karya Soekarno, buku-buku yang dibaca Soekarno, karya orang lain tentang Soekarno dan karya para pejuang bangsa, koleksi arsip yang disimpan di perpustakaan Bung Karno adalah semua barang-barang peninggalan Soekarno dan barang bersejarah mulai dari naskah teks Proklamasi, foto-foto tentang kegiatan
Soekarno. Koleksi ini masuk ke dalam koleksi Arsip Negara karena nilai dan makna dari masing-masing sangatlah berharga dan mempunyai nilai sejarah yang sangat tinggi sehingga harus diarsipkan dan dikelola oleh pemerintah sebaik mungkin dan Perpustakaan Nasional sudah sangat tepat untuk mengelola arsip ini karena sesuai fungsi dan tujuan dari lembaganya.

4. Museum

Berfungsi mengumpulkan, merawat, dan menyajikan serta melestarikan warisan budaya masyarakat untuk tujuan studi, penelitian dan kesenangan atau hiburan, Gedung memiliki makna filosofis terkait perjalanan hidup Bung Karno, Blitar terkenal sebagai kota proklamator dan kota peta karena berhasil melawan
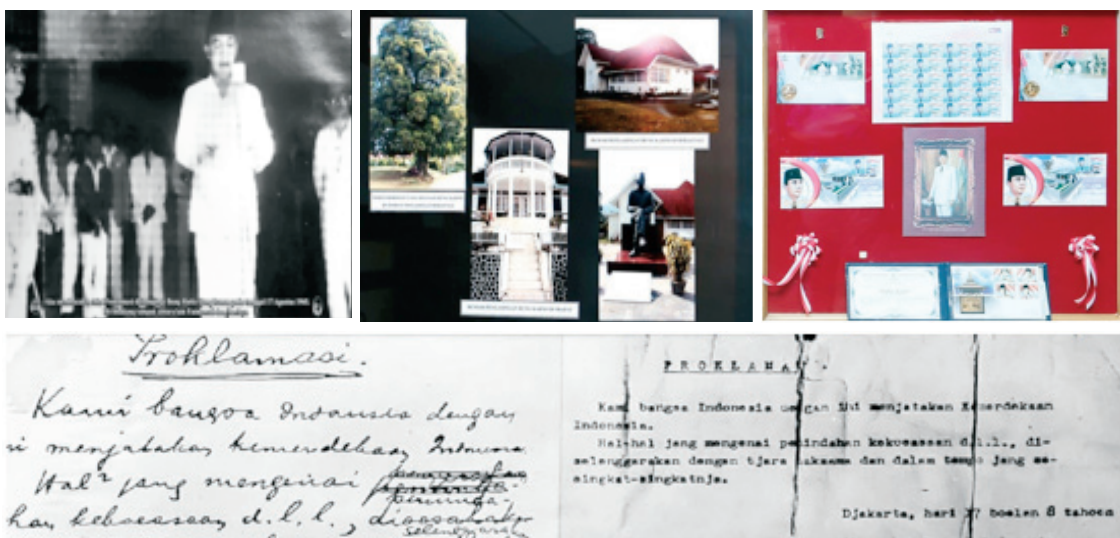

denges fina salsama das dalas

tempooh pang cesing h.t singhal

ria.

Dabarta, $17-8-105$

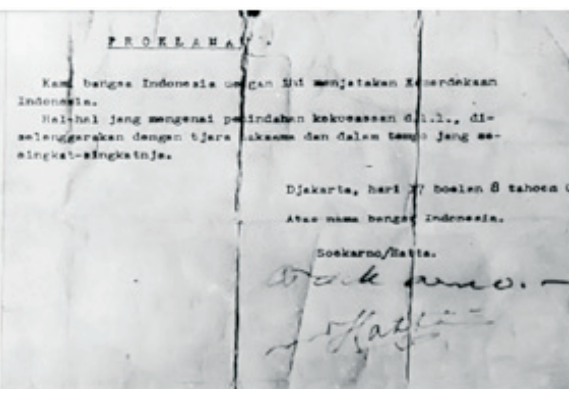

Gambar 6. Sumber: http://perpusbungkarno.perpusnas.go.id/web/index.php/galeri

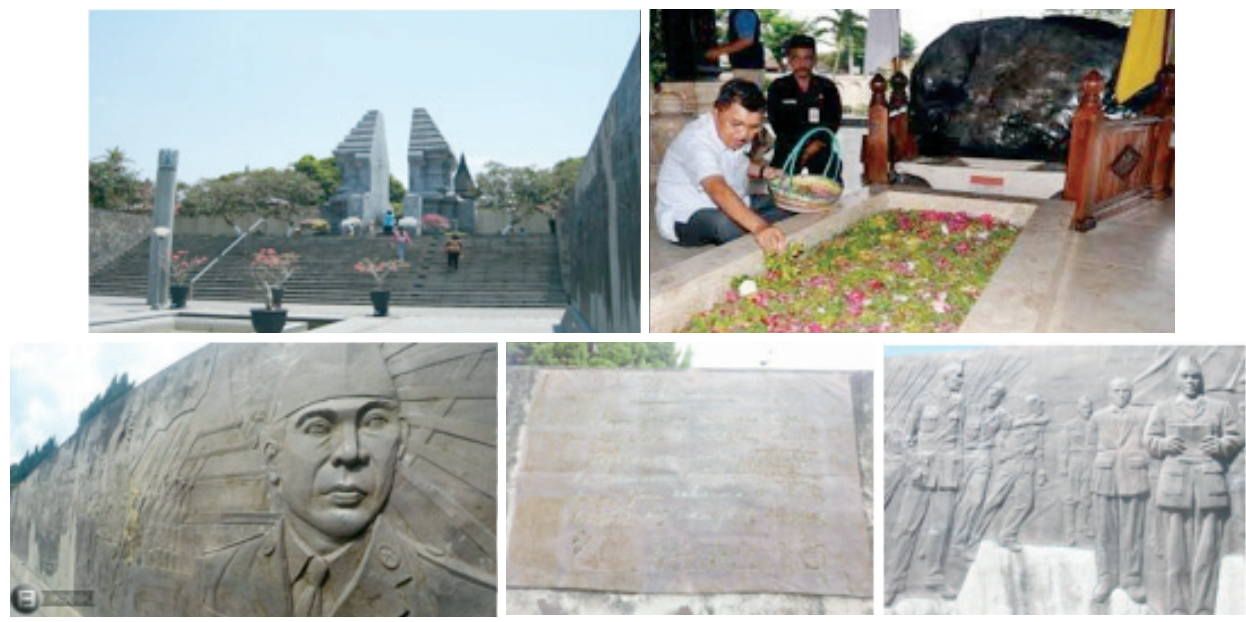

Gambar 7. Sumber: https://www.google.co.id/search?q=museum+proklamator+bung+karno 
Jepang, letak perpustakaan menyatu degan makam, artefak dan relief tentang Bung Karno. Dapat dijadikan konsep museum karena di perpustakaan Bung Karno terdapat relief tentang Bung Karno dan juga makam Bung Karno sebagai simbol dan sejarah Kemerdekaan bangsa Indonesia seperti di museum Tsunami Aceh untuk mengenal korban bencana Tsunami.

\section{KESIMPULAN}

Dari pembahasan tersebut dapat diambil beberapa kesimpulan bahwa:

Perkembangan ilmu pengetahuan dan teknologi menuntut instansi perpustakaan memberikan sesuatu yang baru dan menarik agar dapat dimanfaatkan koleksinya dan produknya oleh masyarakat luas tanpa terkecuali. Konsep GLAM atau dikenal dengan Four Cultural Heritage Domains sangat bagus dikembangkan dan diterapkan di Indonesia agar kegiatan dan pelayanan kepada masyarakat lebih bagus lagi.

Perpustakaan Proklamator Bung Karno sudah memenuhi kriteria Four Cultural Heritage Domains dan sudah memenuhi konsep GLAM sehingga harusnya tidak hanya perpustakaannya saja yang diunggulkan tetapi juga gallery, archive dan musseum juga harus dimaksimalkan keberadaannya. Dengan adanya penerapan konsep GLAM di Perpustakaan Bung Karno diharapkan dapat menjadi pelopor munculnya konsep GLAM oleh perpustakaan lain di Indonesia. Selain itu adanya konsep GLAM juga dapat menarik minat kunjungan masyarakat ke kota Blitar tidak hanya dari dalam kota maupun luar kota, tetapi diharapkan dari mancanegara juga berkunjung ke Perpustakaan Bung Karno karena di sana banyak sekali menyimpan fakta sejarah dan perjuangan bangsa Indonesia. Keberadaan sosok seorang Soekarno sebagai Presiden Pertama di Indonesia akan menjadi daya tarik yang luar biasa apabila dijadikan konsep yang menarik untuk mengemas informasi yang ada di Perpustakaan Proklamator Bung Karno.

Di sisi lain paper ini juga bertujuan agar dapat menjadi bahan tambahan penelitian dan kajian ilmiah di bidang kearsipan karena masih sangat sedikit kajian tentang kearsipan. Saran kepada pihak terkait agar lebih diperhatikan masalah kearsipan di Indonesia agar pengemasan arsip di Indonesia lebih baik lagi.

\section{REFERENSI}

Aycock, A. 2002. Cyndi list: Libraries, archives, and museums. UNESCO Archives Portal, 127 (6), 32.

Development, W. 2012. Galleries, libraries, archives, records and museums workforce strategy. Innovation \& Business Skills Australia, (February), 1-10.

Ghosh, M. 2015. ATALM annual conference on Indigenous Archives, Libraries, and Museums. Library Hi Tech News, 32(4), 14-16.

Hindal, S., \& Wyller, E.H. 2011. Library and museumaAuthority - our role in a society based on knowledge and culture. The Norwegian Archive, 53 (4), 207-212.

Hedegaard, R., \& Hedegaard, R. 2011. The benefits of archives, libraries and museums working together: A Danish case of shared databases, 105 (1202/1203), 290-296.

Indonesia. Kementerian Tenaga Kerja dan Transmigrasi. 2009. Keputusan Direktur Jenderal Pembinaan Pelatihan dan Produktivitas Nomor: KEP.161/Lattas/ X/2008 tentang Pedoman Tata cara Penulisan Standar Kompetensi Kerja Nasional Indonesia. Jakarta: Kementerian Tenaga Kerja dan Transmigrasi RI.

Lim, S., \& Liew, C.L. 2011. Metadata quality and interoperability of GLAM digital images. Aslib Proceedings, 63(5), 484-498.

Marcum, D. (2014). Archives, libraries, useums: Coming Back Together, 49(1), 74-90.

Riley-huff, D.A., Herrera, K., Ivey, S., Harry, T., Riley-huff, D.A., Herrera, K., Harry, T. 2016. Crowdfunding in libraries, Archives and Museums, 29 (2), 67-85.

Sulistyo-Basuki. 2001. Dasar-Dasar Dokumentasi. Jakarta: Universitas Terbuka.

Sulistyo-Basuki.1996. Pengantar Kearsipan. Jakarta: Universitas Terbuka.

Sulistyo-Basuki. 2010. Metode Penelitian. Jakarta: Penaku.

Surachman, A. 2009. Undang-Undang Nomor 43 Tahun 2007: Peluang dan Tantangan Bagi Pustakawan. Diakses, Sabtu 29 April 2017 http://arifs.staff.ugm. ac.id/mypaper/

Wiranto, F.A. 2009. UU Perpustakaan Memasuki Tahun Kedua: Menunggu Terbitnya Peraturan Pemerintah. Genta Pustaka, 3 (14), Januari-Juni. Semarang: Unika Soegijapranata. 